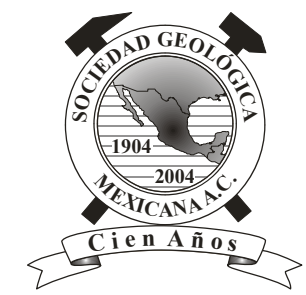

\title{
First record of Procaeculus (Acari: Caeculidae) in Miocene amber from Chiapas, Mexico
}

\author{
Gerardo Rivas ${ }^{1}$, Lourdes Serrano-Sánchez ${ }^{2}$, Francisco J. Vega ${ }^{3, *}$ \\ ${ }^{1}$ Facultad de Ciencias, Universidad Nacional Autónoma de México, Ciudad Universitaria, Coyoacán, 04510, CDMX, Mexico. \\ ${ }^{2}$ Posgrado de Ciencias de la Tierra, Instituto de Geología, Universidad Nacional Autónoma de México, Ciudad Universitaria, \\ Coyoacán, 04510, CDMX, Mexico. \\ ${ }^{3}$ Instituto de Geología, Universidad Nacional Autónoma de México, Ciudad Universitaria, Coyoacán, CDMX, 04510, Mexico. \\ *vegver@unam.mx
}

\begin{abstract}
The first Procaeculus Jacot 1936 (Acari: Trombidiformes: Caeculidae) is reported from the Miocene amber of Chiapas, Mexico. This is the third record for the genus in amber, the other two are from the Baltic (Eocene) and the Dominican Republic (Miocene).
\end{abstract}

Keywords: Crabs, Mite, Caeculidae, amber, lower Miocene, Mexico.

\section{Resumen}

Se reporta por primera vez a Procaeculus Jacot 1936 (Acari: Trombidiformes: Caeculidae) en ámbar del Mioceno de Chiapas, México. Este constituye el tercer registro del género en ámbar, los otros dos corresponden a ámbar del Báltico (Eoceno) y de República Dominicana (Mioceno).

Palabras clave: Ácaro, Caeculidae, ámbar, Mioceno inferior, México.

\section{Introduction}

Approximately 55000 species of mites are described worldwide (Walter and Proctor, 1999), 2625 of which are known from Mexico (Pérez et al., 2014). They demonstrate a wide range of habitats and habits in living chelicerate arthropods, being terrestrial and aquatic with predatory, phytophagous, saprophagous, phycophagous, and parasitic species (Krantz, 2009).

Mites are scarce in the fossil record because their usual size range is from 0.3 to $3 \mathrm{~mm}$. Despite this, a relatively significant number of specimens from all mite orders are known from Eocene and Miocene amber deposits. The oldest fossil record is that of Hirst (1923), who described Protacarus crani from the Devonian of Scotland, and
313 species of the orders Ixodoidea, Mesostigmata, Trombidifomes and Sarcoptiformes Acari have been reported for posterior geologic periods (Dunlop et al., 2015).

Ten species of mites have been recorded in Miocene amber from Chiapas (Norton and Poinar, 1993): Dendrolaelaps fossilis Hirschmann, 1971; Amphicalvolia hurdi Türk, 1963; Neoliodes brevitarsus (Woolley, 1971), Mochloribatula smithi (Woolley, 1971), Oppia mexicana (Woolley, 1971), O. setigera (Woolley, 1971), Benoibates chiapasensis (Wooley, 1971), Parapirnodus denaius (Wooley, 1971), Scheloribates durhami (Woolley, 1971) and Arthrovertex hurdi (Woolley, 1971), the first species belongs to the Mesostigmata and the rest to the Oribatida (Sarcoptiformes).

Caeculidae, commonly known as "rake-legged mites", 
due to the notorious rigid setae on the first pair of legs that are raptorial appendages, used to capture collembols and other mites, though one study demonstrated that they can feed on fungus (Crossley and Merchant, 1971).They move slowly and although they are relatively large in size, are cryptically colored mites and their brown and gray colors are ideal for camouflage (Walter et al., 2009). Their hardened body is covered by eight dorsal sclerites, sometimes fused. Caeculids are often thermophilous and found in rocky habitats, some associated with vegetation. A species was noted associated with ant Messor pergandei in desert (Uppstrom and Klompen, 2011).

Worldwide, Caeculidae includes 99 described species (Taylor et al., 2013) arranged in seven genera: Allocaeculus Franz, 1952; Andocaeculus Coineau, 1969; Caeculus Dufour, 1832; Calocaeculus Coineau, 1969, Microcaeculus Franz, 1952; Neocaeculus Coineau, 1969 and Procaeculus Jacot, 1936. Seven caeculid species have been are reported from Mexico (Vázquez-Rojas and López-Campos, 2013): Caeculus dorothae Mulaik, 1945; C. hardyi Mulaik and Allred, 1954; C. tipus Mulaik, 1945; C. valverdius Mulaik, 1945; Procaeculus mexicanus (Mulaik and Allred, 1954); $P$. orchidicolis (Mulaik and Allred, 1954) and P.potosi (Mulaik and Allred, 1954).

Extant species of Procaeculus are: P. bryani Jacot,
1936 from Hawaii; P. brevis (Mulaik, 1945) from Texas; $P$. puertoricus (Mulaik, 1945) from Puerto Rico; P. mexicanus (Mulaik and Allred, 1954) and P. potosi (Mulaik and Allred, 1945) from Mexico; P. orchidolis (Mulaik and Allred, 1945) from Guatemala and Mexico; P. willmanni (Vitzthum, 1933) from Hawaii and P. magnus Coineau, 1969 from Texas.

There are only two known Caeculidae species preserved in amber: Procaeculus eridanosae Coineau and Poinar, 2001 from the Eocene of Poland and P. dominicensis Coineau and Magowski, 1994 from the Miocene of the Dominican Republic.

\section{Locality and material}

The amber from Simojovel, Chiapas is considered to be the result of leguminosae resin, deposited in an estuarine environment near to the ancient gulf coast, in early Miocene times (Poinar and Brown, 2002; Solórzano-Kraemer, 2010; Perrilliat et al., 2010; Riquelme et al., 2014; SerranoSánchez et al., 2015). Two amber pieces (IHNFG-4924 and IHNFG-4982) include two adults and a molt of Caeculidae mites. Associated fauna includes ostracods, insect remains, sand grains and organic matter. The amber pieces were collected at Campo La Granja mines, north of the town
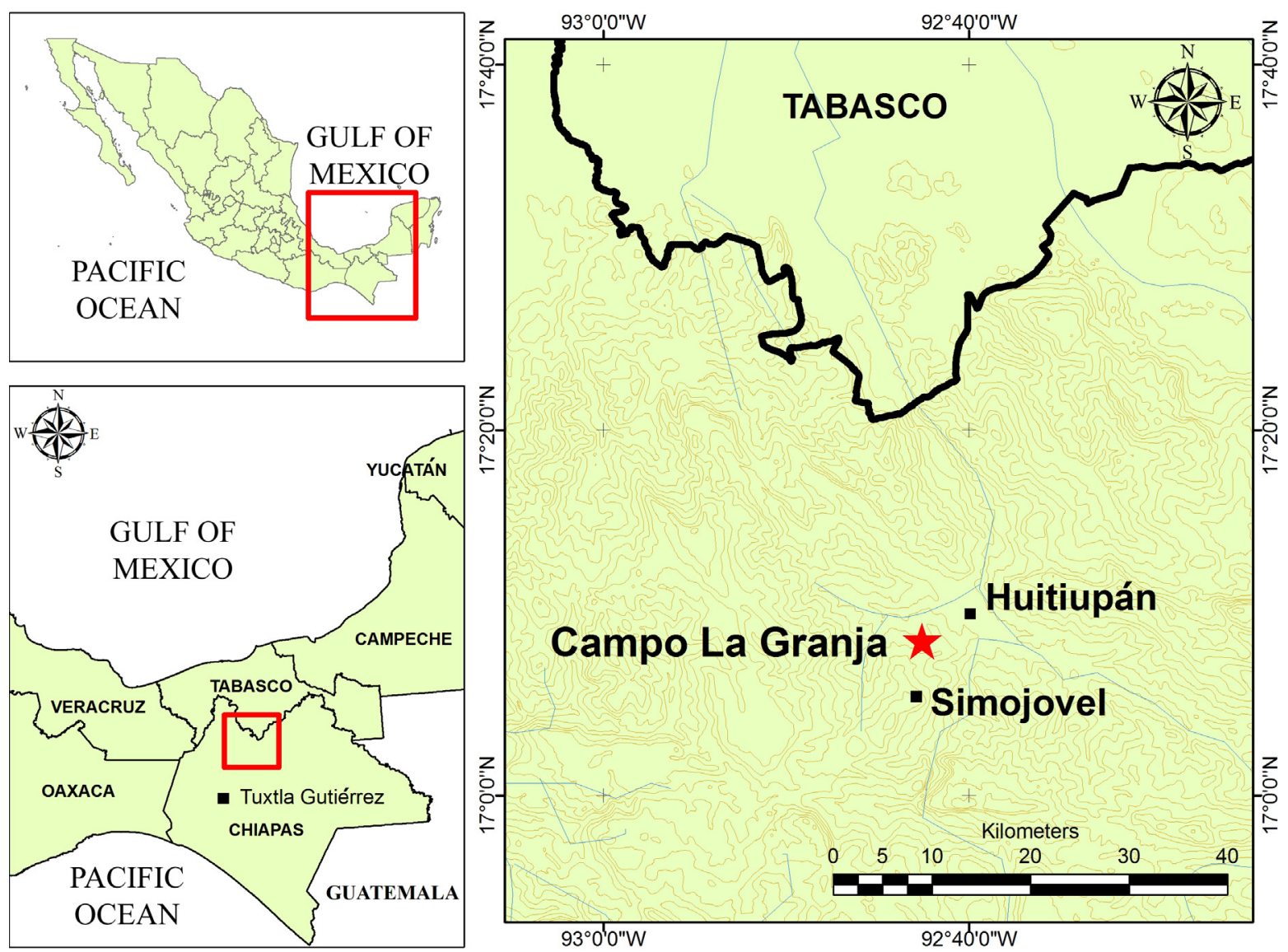

Figure 1. Location map of Campo La Granja mines, Chiapas, southeast Mexico. Modified after Serrano-Sánchez et al., 2015 
of Simojovel (Figure 1), in sediments that include mainly quartz sandstones of the upper portion (Finca Carmitto Member) of the lower Miocene La Quinta Formation (Frost and Langenheim, 1974; Serrano-Sánchez et al., 2015). The peculiar contents (brackish water, freshwater and terrestrial organisms) and shape of amber pieces from Campo La Granja mines (mainly stratified amber with sandstone included into the ambar) suggest the resin was deposited in a tidal flat environment near the ancient Gulf of Mexico coastline (Serrano-Sánchez et al., 2015).

The samples are deposited at the Museo de Paleontología "Eliseo Palacios Aguilera", Calzada de los Hombres Ilustres s/n, Tuxtla Gutiérrez, Chiapas, under the acronym IHNFG.

\section{Systematic Paleontology}

Subclass Acari Sundevall, 1833

Superorder Acariformes Krantz, 1978

OrderTrombidiformes Reuter, 1909

Suborder Prostigmata Kramer, 1877

Infraorder Anystina van der Hammen, 1872

Superfamily Caeculoidea Berlesse, 1883

Family Caeculidae Berlesse, 1883

Genus Procaeculus Jacot, 1936

Figures 2, 3, 4

Description. Idiosome slightly longer than wide, 358 $\mu \mathrm{m}$ from base of pedipalps to posterior end of body and $282 \mu \mathrm{m}$ maximum width. No dorsal plates are evident (Figure 2a), only the posterior edge of aspidosomal plate is visible (Figure 3a), a pair of ocelli on each side is visible in this same region. From well-defined tubercles, two long and claviform trichobothria or bothridal setae are found at anterior edge of aspidosomal plate (Figures 2b, 3a); distally and beside each seta, an equally long trichobothrium arise from a corniculum-shaped projection. The chelicerae are clearly distinct from gnathosoma but not its segments. Pedipalps are visible in lateral view (Figure 2c), with a well-developed unguiform tibial setae. Tarsal chaetotaxia is unclear on the pedipalp. Legs folded ventrally between femur and tibia, making it difficult to observe tarsi and features of its claws. Rigid and spiniform setae, typical of caeculids can be observed on ventral side of first pair of legs: one on basifemur, two on genua and two on tibia (Figures 2d, 3b), one claviform setae on telofemur, as long these segments (Figure 3b). Leg trochanters robust with spatulate setae (Figures 2e, 3a). This kind of setae should also be found at the dorsal portion of idiosoma, but are not visible in the study specimens.

In the nearly complete specimen of piece IHNFG-4982, an exuvia was also preserved and it possibly belongs to the same mite. The exuvia preserves trochanter of legs I - III (Figure 2f), as well as rigid and spiniform setae on first leg. No idiosome or gnathosome is visible in this exuvia. A second specimen (IHNFG-4924) scarcely shows a partial dorsal view (Figures 4a-4c). However, in this specimen, another view of the spinorms setae of legs and the lateral view of pedipals can be seen (Figure 4d) and the aspidosomal plate has one pair of large trichobothria (Figure 4b).

Discussion. The mite of our study is the first fossil record for the Trombidiformes order in Mexico. This represents an important contribution to the fossil record from the Chiapas Miocene and also for the knowledge of acarologist diversity from Mexico.

The caeculid mite found in Miocene amber belongs to Procaeculus, a genus with two known fossil species. The spiniform setae on first pair of legs and location of trichobothria on antero-dorsal (aspidosomal) plate, are all diagnostic features to place the specimen within the Caeculidae.

Procaeculus is characterized by having relatively narrow aspidomal (antero-dorsal) plate (Coineau, 1967) as the case of our Mexican specimen. The concave shape of anterior margin of the aspidosomal plate and the possibility to observe pedipalps and chelicerae in dorsal view (this plate not projected anteriorly), are the two main features that allow to place the specimen within the genus Procaeculus Jacot, 1936.

For the moment, it is not possible to identify the specimen at species level, since details of pedipalps are difficult to observe, particularly the claw-tibia-tarsus complex, tarsus of legs (the distal portions are folded) and the chaetotaxia and shape of idiosoma plates in dorsal view.

Only two fossil species for the genus have been reported so far. Procaeculus eridanosae from the Eocene amber of Poland has a narrow and not so acute anterior portion of the aspidosomal plate. $P$. dominicensis from the Miocene Dominican amber is similar to our specimen in the shape of the anterior margin of antero-dorsal plate, but trichobothria (bo) in the Mexican specimen are larger and the anterodorsal plates wider than long.

Although caeculid mites are typical in terrestrial environments (mountains and arid regions), associated with fallen leaves and bark, some extant species i.e. Microcaeculus Franz, 1952 are found in littoral zones (Coineau, 1969; Otto, 1993). Thus, this range of tolerance and ecophysiological plasticity may explain the presence of a caeculid mite in estuarine environments, such as the one where the studied piece of amber was deposited.

\section{Acknowledgements}

We are grateful to Christopher Taylor, José Palacios, Ignacio Vázquez and Griselda Montiel for their valuable support with bibliographic references. Support during the postgraduate studies of M.L. Serrano from Posgrado en Ciencias de la Tierra, Instituto de Geología, UNAM and CONACYT is highly appreciated. We appreciate valuable corrections of two anonymous reviewers. 

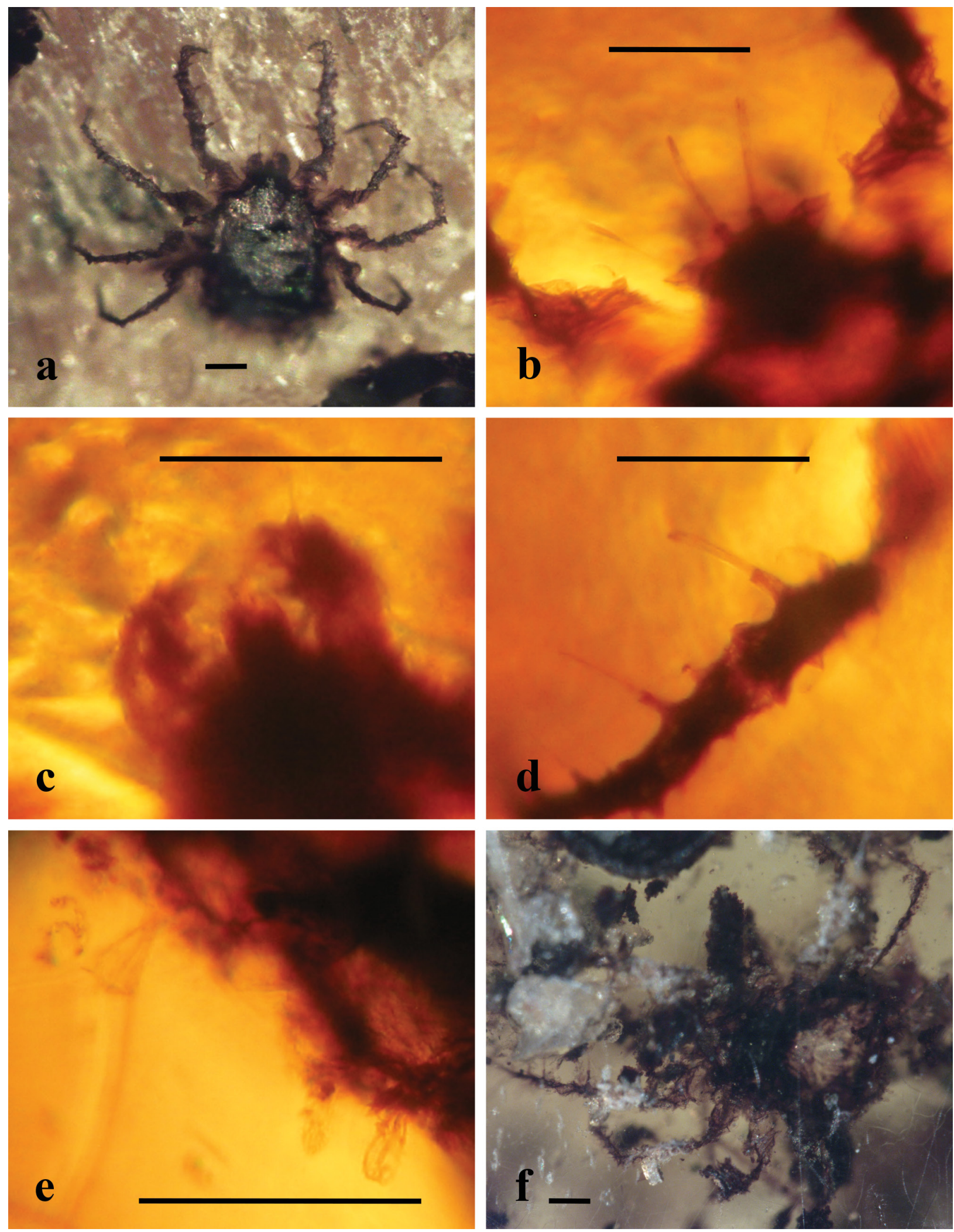

Figure 2. Procaeculus (Acari: Trombidiformes) in lower Miocene amber of Chiapas, Mexico, IHNFG-4982). a) Complete specimen in dorsal view. b) Trichobothria setae on anterior portion of the aspidosomal plate. c) Gnathosoma: pedipalp sand chelicerae in central portion. d) Spiniform setae of first pair of legs. e) Spatulate setae in trochanter of first pair of legs. f) Spiniform setae in exuvia. Scale bar $=100$ microns. 

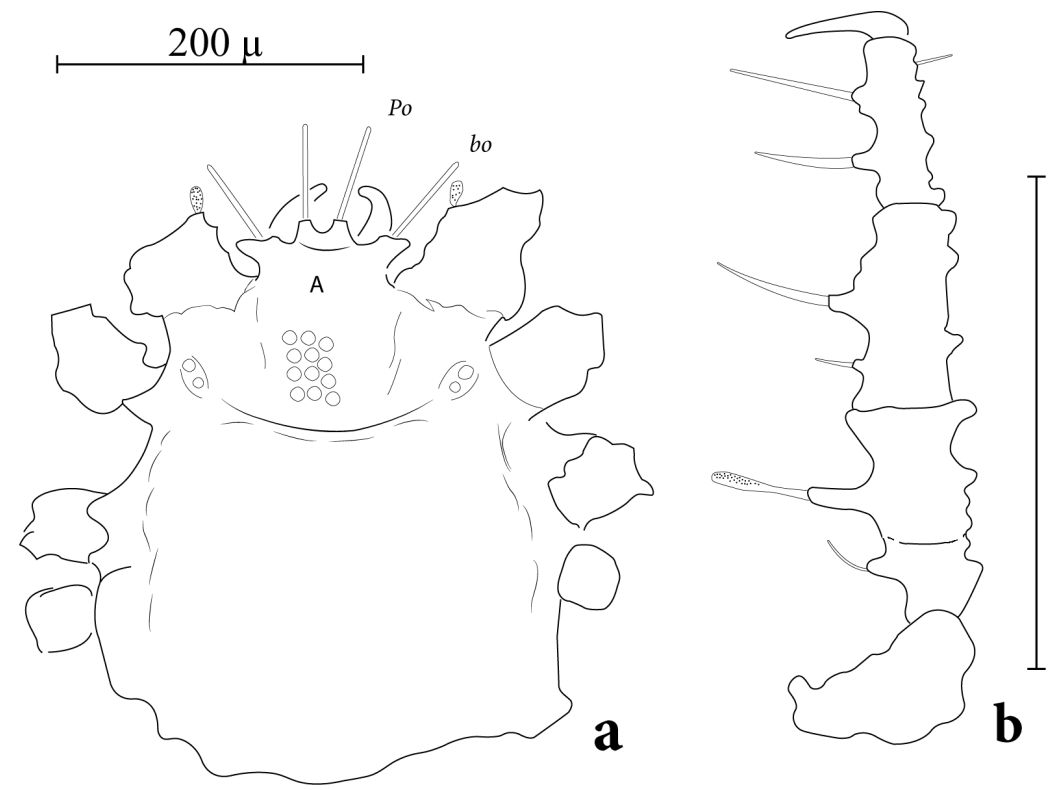

Figure 3. Procaeculus (Acari: Trombifidormes) in lower Miocene amber of Chiapas, Mexico, IHNFG-4982). a) Idiosoma in dorsal view. A = aspidosomal plate, $\mathrm{Po}=$ proximal trichobothria, $\mathrm{bo}=$ distal trichobothria. $\mathrm{b}$ ) First leg. Scale bars $=200$ microns.
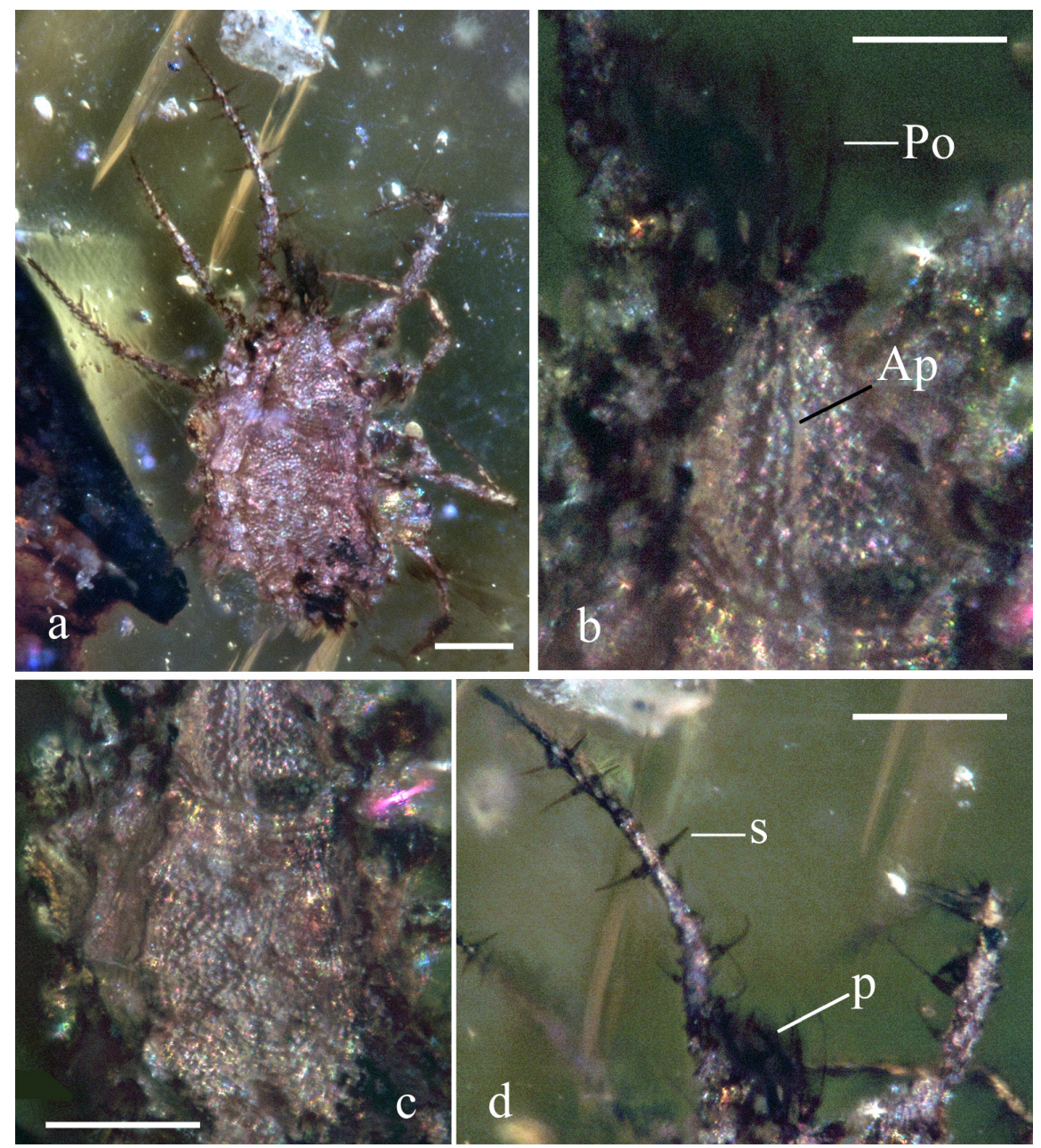

Figure 4. Procaeculus (Acari: Trombidiformes) in lower Miocene amber of Chiapas, Mexico, IHNFG-4924). a) Second specimen in partial dorsal view. b) Proximal tricobathria (Po) setae on anterior portion of the aspidosomal plate (Ap). c) Close up to dorsal surface. d) Spiniform setae (s) on first leg and pedipalp $(p)$ in lateral view. Scale bars $=100$ microns. 


\section{References}

Coineau, Y., 1967, Contribution à l'étude des Caeculidae. IV. Procaeculus bryani Jacot, 1936 (Acariens: Prostigmates): Pacific Insects, 9, 4, 709-720.

Coineau, Y., 1969, Contribution à l'étude des Caeculidae. Sixième série. Microcaeculus sabulicola Franz 1952. Redescription, chétotaxie et répartition: Acarologia, 11, 2, 207-221.

Coineau, Y., 1974, Eléments pour une monographie morphologique, écologique et biologique des Caeculidae (Acariens): Mémoires du Muséum d'Histoire naturelle, Paris, Série A Zoologie, T. 81, 299 p.

Coineau, Y., Magowski, W.Ł., 1994, Caeculidae in amber: Acarologia, 35, 3, 243-246.

Coineau, Y., Poinar, G., 2001, Un Caeculidae de l'ambre de la République Dominicaine: Acarologia, 41, 1-2, 141-144.

Crossley, D.A., Merchant, V.A., 1971, Feeding by caeculid mites on fungus demonstrated with radioactive tracers: Annals of the Entomological Society of America, 64, 760-762.

Dufour, L., 1832, Description et figure du Caeculus echinipes, Arachnide nouvelle: Annales des Sciences naturelles, Série 1, 25, 289-296.

Dunlop, J.A., Penney, D., 2015, A summary list of fossil spiders and their relatives, in World Spider Catalog. Natural History Museum Bern, online at http://wsc.nmbe.ch, version 15.5, accessed on $\{10.03 .2015\}$. Last updated: 09.01.2016

Franz, H., 1952, Revision der Caeculidae Berlese 1883 (Acari):Bonner Zoologische Beitrage, 3, 9-124

Frost, S.H., Langenheim, R.L., 1974, Cenozoic reef biofacies, Tertiary larger Foraminifera and scleractinian corals from Chiapas, Mexico. De Kalb (IL): Northern Illinois University Press. 388 p.

Hirschmann, W., 1971, Afossil mite of the genus Dendrolaelaps (Acarina, Mesostigmata, Digamasellidae) found in amber from Chiapas, Mexico: University of California Publications in Entomology, 63,69-70.

Hirst, S., 1923, On some arachnids remains of Old Red Sandstone (Rhynie Chert Bed, Aberdeenshire): Annals and Magazine of Natural History, $12,455-474$.

Jacot, A.P., 1936, Some rake-legged mites of the family Cheyletidae: Journal of the New York Entomological Society, 44, 17-30.

Krantz, G.W., 2009, Habits and habitats, in Krantz, G.W., Walter, D.E. (eds.), A manual of Acarology, Third edition, Lubbock Texas, Texas TechUniversity Press, 64-82.

Mulaik, S., 1945, New mites in the family Caeculidae: Bulletin of the University of Utah, 35, 17, 1-23.

Mulaik, S., Allred, D.M., 1954, New species and distribution records of the genus Caeculus in North America: Proceedings of the Entomological Society of Washington, 56, 27-40.

McDaniel, B., Boe, A., 1990, A new species and distribution record for the genus Caeculus Dufour (Acari: Caeculidae) from South Dakota: Proceedings of the Entomological Society of Washington, 92, 4, 716-724.

Norton, R.A., Poinar, G.O., 1993, Reassessment and new records of oribatid mite fossils from Tertiary Neotropical amber: Acarologia, $34,1,57-68$.

Otto, J.C., 1993, A new species of Microcaeculus from Australia (Acarina: Caeculidae), with notes on its biology and behavior: International Journal of Acarology, 19, 1, 3-13.
Pérez, T.M., Guzmán-Cornejo, C., Montiel-Parra, G., Paredes-León, R., Rivas, G., 2014, Biodiversidad de ácaros en México: Revista Mexicana de Biodiversidad, 85, 399-407.

Perrilliat, M.C., Vega, F.J., Coutiño, M., 2010, Miocene mollusks from the Simojovel area, Central Chiapas, southwestern Mexico: Journal of South American Earth Sciences, 30, 111-119.

Poinar, Jr. G, Brown, A., 2002, Hymenaea mexicana sp. nov. (Leguminosae: Caesalpinioideae) from Mexican amber indicates Old World connections: Botanical journal of the Linnean Society, 139, 2, 125-132.

Riquelme, F., Northrup, P., Ruvalcaba-Sil, J.L., Stojanoff, V., Siddons, D.P., Alvarado-Ortega, J., 2014, Insights into molecular chemistry of Chiapas amber usingin frared-light microscopy, PIXE/RBS, and sulfur K-edgeXANES spectroscopy: Applied Physics A, 116, 97-109.

Serrano-Sánchez, M.L., Hegna, T.A., Schaaf, P., Centeno-García, E., Pérez, L., Vega, F.J., 2015, The aquatic and semiaquatic biota in Miocene amber from the Campo La Granja mine (Chiapas, Mexico): paleoenvironmental implications: Journal of South American Earth Sciences, 62, 243-256.

Solórzano-Kraemer, M.M., 2010, Mexican amber, in Penney, D. (ed.), Biodiversity of fossils in amber from the major world deposits: Manchester, UK, Siri Scientific Press, 42-56.

Taylor, Ch.K., Gunawardene, N.R., Kinnear, A., 2013, A new species of Neocaeculus (Acari: Prostigmata: Caeculidae) from Barrow Island, Western Australia, with a checklist of world Caeculidae: Acarologia, $53,4,439-452$

Türk, E., 1963, A new tyroglyphid deutonymph in amber from Chiapas, Mexico: University of California Publications in Entomology, 31, 49-51.

Vázquez-Rojas, I., López-Campos, M.G., 2013, Los ácaros depredadores de la familia Caeculidae, in Estrada Venegas, E.G., Chaires Grijalva, M.P., Acuña Soto, J.A., Equihua Martínez, A. (eds.), Fauna del Suelo II micro, meso y macrofauna 18-27: México, Colegio de Postgraduados, 18-27.

Uppstrom, K.A., Klompen, H., 2011, Mites (Acari) Associated with the Desert Seed Harvester Ant, Messor pergandei (Mayr). Psyque, DOI: http://dx.doi.org/10.1155/2011/974646.

Vitzthum, H.G., 1933, Die Larvenform der Gattung Caeculus: Zoologische Anzeiger, 105, 85-92.

Walter, D.E., Proctor H.C., 1999, Mites: Ecology Evolution and Behavior: Centre for Agricultural Bioscience International, $322 \mathrm{p}$.

Walter, D.E., Lindquist, E.E., Smith, I.M., Cook, D.R., Krantz, G.W., 2009, Order Trombidiformes, in Krantz, G.W.,Walter, D.E. (eds.), A manual of Acarology, Third edition, Lubbock, Texas, Texas Tech University Press, 233-420.

Woolley, T.A., 1971, Fossil oribatid mites in amber from Chiapas, Mexico (Acarina: Oribatei $=$ Cryptostigmata): University of California Publications in Entomology, 63, 91-99.

Manuscript received: January 18, 2015

Corrected manuscript received: March 23, 2015

Manuscript accepted: March 30, 2015 